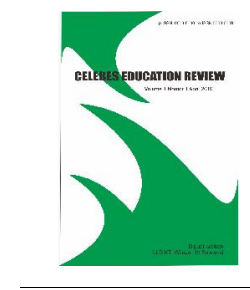

\author{
Celebes Education Review \\ http://journal.lldikti9.id/CER \\ Vol 1, No, 2, October 2019, pp 112-116 \\ p-ISSN: $\underline{\text { 2656-7385 }}$ dan e-ISSN: $\underline{\text { 2684-7124 }}$
}

\title{
Increasing Understanding Of Reading Through Sustained Silent Reading (SSR) At The Second Grade Students Of English Department of STKIP PGRI Bangkalan
}

\author{
Mohammad Arief Wahyudi \\ Pendidikan Bahasa Inggris, STKIP PGRI Bangkalan \\ Email: arwah74@stkippgri-bkl.ac.id
}

Artikel info

Artikel history:

Received; 9-09-2019

Revised:21-09-2019

Accepted;24-10-2019
Abstract. There are five skills in learning English, namely reading, speaking, listening and writing. The five skills are related to one another. This has been taught from elementary to high school so all students must understand it. In reading skills (Reading), students must understand a reading technique because without understanding they will not understand the contents of the reading or the information contained therein. This was experienced by students in the second semester, especially the English department who was in STKIP PGRI Bangkalan. In solving the problem above, the researcher aims to introduce the method used by the lecturer, the Sustained Silent Reading (SSR) Method. This method can help lecturers to invite students to find information and express ideas or ideas. This research method is quantitative in the experimental study where there is only one class of 30 students in one group pre-test and post-test. From these results it can be concluded that there is significant progress between the mean score 34 in the pre-test and the post-test score 73.

Abstrak. Ada Lima keterampilan dalam mempelajari bahasa Inggris yaitu membaca, berbicara, mendengarkan dan menulis. Kelima keterampilan tersebut berkaitan satu dengan yang lainnya. Hal ini telah diajarkan dari sekolah tingkat bawah sampai perguruan tinggi sehingga semua siswa harus memahaminya. Dalam keterampilan membaca (Reading), siswa harus memahami suatu tek bacaan karena tanpa memahami mereka tidak akan mengerti isi bacaan atau informasi yang ada dalamnya. Hal ini dialami oleh mahasiswa semester Dua khususnya jurusan Bahasa Inggris yang berada di STKIP PGRI Bangkalan. Dalam menyelesaikan masalah tersebut diatas maka peneliti bertujuan untuk memperkenalkan metode yang pakai oleh dosen yaitu Metode Sustained Silent Reading (SSR). Metode ini bisa membantu dosen untuk mengajak mahasiswa dalam menemukan informasi dan mengekspresikan ide atau gagasan. Metode 
penelitian ini adalah Kuantitatif dalam eksperimental yang di mana hanya terdapat satu kelas yang berjumlah 30 mahasiswa dalam one group pre- tes dan post- tes. Dari hasil penelitian tersebut dapat disimpulkan adanya kemajuan yang signifikan diantara rata- rata skore 34 pada pre- tes dan skore post- test 73

Keywords:

Metode, Peningkatan, Sustained Silent Reading
Coresponden author:

Email: arwah74@stkippgri-bkl.ac.id

artikel dengan akses terbuka dibawah lisensi CC BY -4.0

\section{Pendahuluan}

Membaca memberikan banyak inspirasi dan manfaat, wawasan dan pengetahuan baru yang senantiasa bertambah bagi pembacanya. Membaca adalah suatu keterampilan paling mendasar bagi semua siswa. Siswa diharapkan memiliki pemahaman yang baik suatu tek yang mereka baca terutama dalam bahasa Inggris. Didalam buku Reading Power yang ditulis oleh Beatrice S. Mikulecky dan Linda Jeffries (2004: 6) bahwa kegiatan membaca mampu meningkatkan kecakapan bahasa Inggris mahasiswa, antara lain: 1) Membaca mampu membantu mahasiswa belajar berpikir dalam bahasa Inggris. 2) Membaca mampu memperkaya kosakata dalam bahasa Inggris. 3) Membaca mampu membantu mahasiswa memperbaiki kemampuan menulis mahasiswa. 4) Membaca adalah salah satu cara kegiatan untuk melatih dan menyiapkan mahasiswa belajar bahasa Inggris ketika mereka terjun langsung ke negara lain baik yang menggunakan bahasa Inggris maupun yang tidak. 5) Membaca adalah cara efektif untuk menemukan ide baru, fakta, dan pengalaman.

Namun kenyataannya siswa yang mempelajari bahasa Inggris tetap menghadapi permasalahan dalam memahami suatu teks. Hal ini disebabkan kurang tertariknya dalam proses membaca yang disebabkan terbatasnya kemampuan mereka dalam menguasai kosa kata dalam bahasa Inggris. Permasalahan ini dialami oleh mahasiswa semester Dua khususnya jurusan Bahasa Inggris di STKIP PGRI Bangkalan. Walau mereka jurusan bahasa Inggris tetapi terkadang mengalami kesulitan.

Dalam menyelesaikan permasalahan ini maka peneliti mencari solusi yaitu dengan memperkenalkan Metode Sustained Silent Reading (SSR). Metode ini adalah suatu proses preview (dimana siswa membaca setiap kalimat dalam setiap paragraph), predict what comes next, read the whole texts silent dan discussion. Metode Sustained Silent Reading (SSR) ini dikemukakan oleh Gardiner (2005: 15) yang menjelaskan bahwa Pengertian Sustainend Silent Reading adalah waktu membaca secara bersama- sama dikelas secara diam atau tenang selama waktu yang ditentukan yaitu 15 sampai 20 menit. Mahasiswa diijinkan untuk membaca bacaan mereka sendiri dan membaca secara mandiri. Tentu saja buku bacaan mereka harus berbahasa Inggris disesuaikan dengan jurusan mereka di Pendidikan Bahasa Inggris. Tujuan dari program ini adalah untuk meningkatkan minat membaca pada anak- anak, membangun motivasi intrinsik sehingga para siswa yang senang membaca tidak perlu lagi didorong untuk membaca, ia dengan sendirinya akan mencari buku-buku untuk dibacanya. Proses yang dilakukan selama membaca adalah: (1) peserta didik menyiapkan buku bacaan yang sudah dibawa dari rumah atau meminjam dari perpustakaan; (2) melaksanakan SSR didampingi guru pada mata pelajaran; (3) menuliskan resume dengan kalimatnya sendiri; (4) peserta didik menyampaikan secara lisan hasil resume yang dibaca keteman sebangkunya secara bergantian; dan (5) mengumpulkan hasil resume kepada guru. Dari keterangan diatas maka muncullah suatu pertanyaan: Apakah 
mahasiswa yang diajarkan menggunakan metode Sustained Silent reading (SSR) lebih baik nilainya di bandingkan mereka yang tidak menggunakan?

\section{Reading}

Henry Guntur Tarigan (2008:7) mengatakan bahwa membaca adalah suatu proses yang dilakukan serta dipergunakan oleh pembaca untuk memperoleh pesan yang disampaikan oleh seorang penulis melalui media kata- kata atau tulisan. Menurut Siahaan dan Purwijayanto (dalam Hartiningsih, 2006: 19) mendefinisikan membaca pemahaman sebagai suatu kegiatan atau membaca yang penekanannya diarahkan pada keterampilan dan menguasai isi bacaan. Pembaca harus mampu menguasai dan memahami bacaan yang dibacanya. Membaca terutama membaca pemahaman bukanlah kegiatan yang pasif. Sebenarnya pada perangkat yang lebih tinggi, membaca bukan sekedar memahami lambang-lambang tertulis, melainkan pula memahami, menerima, menolak, membandingkan, dan meyakini pendapat- pendapat yang ada dalam bacaan. Selain memperkaya pengetahuan, membaca pemahaman juga meningkatkan daya nalar (Tampubolon, 1987). Membaca pemahaman bukanlah teknis atau membaca indah, melainkan membaca untuk mengenal atau menemukan ide baik yang tersurat maupun yang tersirat. Proses ini melibatkan faktor kecerdasan dan pengalaman pembaca, keterampilan bahasa, dan penglihatan. Pencapaian sasaran membaca di dalam hati pada anak-anak sekolah hendaknya harus memperhatikan keterampilan yang dimiliki oleh pembaca dalam hati (Satrijono, 2009:56) yaitu proses membaca dilaksanakan tanpa adanya gerakan kepala, bibir, jangan memikirkan isi bacaan, memahami bacaan secara di dalam hati, berkonsentrasi secara fisik maupun mental dan mengungkapkan kembali isi bacaan secara lisan ataupun tulisan yang dikehendaki oleh guru. Dengan demikian, dapat digambarkan program membaca lima belas menit yaitu dengan menggunakan tujuh dimensi dapat dilihat melalui produktivitas, kualitas, efisiensi, flexibilitas, keunggulan, pengembangan, dan kepuasan (Gibson dkk (1996) dalam Makmur (2008: 127).

a) Produktivitas

Produktivitas merupakan perbandingan antara hasil yang dicapai dengan keseluruhan sumber daya yang digunakan, yang berarti adalah output dari program tersebut. Berdasarkan Kamus Besar Bahasa Indonesia (1991:789) mendefinisikan pengertian dari produktifitas adalah kemampuan untuk menghasilkan sesuatu. Dengan demikian output atau produk dalam program membaca lima belas menit adalah siswa mampu dalam membaca dan menulis.

b) Kualitas

Kualitas pada dasarnya terkait dengan pelayanan yang terbaik, yaitu sikap atau cara seseorang dalam melayani para masyarakat dalam artian mereka adalah para siswa dan siswi. Sehingga untuk melihat pelayanan yang terbaik dalam program membaca lima belas menit yaitu dengan melihat sikap dan cara para guru dalam melayani para siswa ketika dalam pelaksanaan program. Dengan demikian untuk melihat kualitas pelayanan yang terbaik (serve excellence) dapat dilihat dari enam unsur pokok (Barata, 2004:31) yaitu:

1) Kemampuan (Ability)

2) Sikap (Attitude)

3) Penampilan (Appearance)

4) Perhatian (Attention)

5) Tanggung jawab (Accounttability)

c) Efiseinsi

d) Fleksibilitas

Flexibilitas adalah kemampuan organisasi dalam mengubah standar prosedur pelaksanaan program dalam menaggapi perubahan tersebut untuk mencegah kebekuan dalam menghadapai rangsangan lingkungan, hal tersebut menjadi sangat penting karena berhubungan dengan dinamisasi masyarakat dan lingkungan. 
e) Keunggulan

Untuk jangka panjang, tentunya sebuah program ingin terus bertahan, hal tersebut dapat dicapai jika sebuah program memilki keunggulan, artinya suatu produk memiliki daya saing agar dapat menarik para siswa, karena suatu produk jika memilki daya saing maka produk tersebut dibutuhkan oleh para siswa, keunggulan suartu produk informasi terletak pada keunikan serta kualitas pelayanan kepada para siswa.

f. Pengembangan

Pengembangan menjamin efektivitas program melalui investasi sumber daya guna memenuhi permintaan lingkungan mendatang karena usaha- usaha pengembangan yang dikelola dengan baik adalah sebagai kunci lingkungan hidup, pengembangan timbul untuk menanggapai suatu kebutuhan. Pengembangan dalam program membaca lima belas menit adalah adanya sudut baca yang tersedia dikelas ini bertujuan untuk mendekatakan para siswa terhadap buku dan memudahkan akses para siswa untuk mendapatkan bahan bacaannya. g. Kepuasan

Kepuasan merupakan perbedaan antara tingkat kepentingan dan kinerja atau hasil yang dirasakan yang berkaitan dengan perasaaan yang dirasakan peserta, ini berarti bahwa artinya manfaat apa yang dirasa siswa dengan adanya program membaca lima belas menit. Pilgreen dalam Schleper (2002) menyebutkan setidaknya ada delapan factor yang mempengaruhi program tersebut yaitu: Akses, daya tarik, lingkungan yang kondusif, dorongan atau motivasi, pelatihan staff, Non akuntabiltas, follow- up kegiatan, Mendistribusikan waktu untuk membaca. Kedelapan faktor tersebut adalah factor yang mempengaruhi suksesnya program membaca lima belas menit atau Sustained Silent Reading (SSR).

\section{Metode Penelitian}

Metode penelitian ini maka peneliti menggunakan kuantitatif yaitu pre- ekperimental desain kerena hanya terdapat satu kelas sehingga one group pre- test dan post- test. Untuk mengukur dari kemampuan mahasiswa dalam memahami suatu teks bacaan maka menggunakan instrument berupa tes.

Menurut John W Creswell, Tabel yang digunakan:

$$
\text { 01--------- X (dua kali) --------------- } 02
$$

Yang digunakan dalam penelitian ini adalah semester Dua pada jurusan bahasa Inggris di STKIP PGRI Bangkalan terdiri dari satu kelas dengan jumlah mahasiswa 30 orang. Yang digunakan yaitu seluruh mahasiswa semester Dua pada jurusan Bahasa Inggris di STKIP PGI Bangkalan yang terdiri dari 30 mahasiswa

\section{Hasil dan Pembahasan}

Hasil yang diperoleh setelah melaksanakan treatmen (Perlakuan) dari nilai Pre- tes dan post- tes ditemukan bahwa terjadi kenaikan signifikan skore mahasiswa menjadi meningkat. Berikut hasil skore yang diperoleh tidak menggunakan dan menggunakan metode Sustained Silent reading (SSR). Ditemukan adanya kemajuan yang signifikan diantaranta rata- rata skore 34 pada pre- tes dan skore post- test 73. Sehingga dari hasil analisis data yang didapat diatas maka peneliti bisa mengasumsi bahwa menggunakan metode Sustained Silent reading (SSR) adalah sangat cocok diterapkan kepada mahasiswa semester Dua di STKIP PGRI Bangkalan.

Dari hasil analisis data dapat didapatkan hipotesisnya yaitu bahwa nilai $\mathrm{T}$ test $>$ dari nilai signifikan $(0,05=5 \%)$ maka hipotesisnya di terima sehingga nilai $\mathrm{T}$ - tesnya adalah 9,086 > 0,3494 artinya Hipothesis Alternatifnya dalam pembelajaran menggunakan metode Sustained 
Silent reading (SSR) diterima dan Null hipothesisnya ditolak. Dengan menggunakan penjelasan diatas dapat dihasilkan analisis data yang didapat, maka peneliti bisa menyimpulkan penggunaan metode Sustained Silent reading (SSR) adalah sangat cocok dan efektif diterapkan kepada mahasiswa semester Dua jurusan bahasa Inggris di STKIP PGRI Bangkalan.

\section{Simpulan}

Berdasarkan hasil penelitian yang didapat bisa disimpulkan bahwa pemakaian metode , Sustained Silent reading (SSR) adalah sangat efektif dengan menggunakan metode Eksperimerntal desain dengan terbuktinya uji T- test setelah diberi dua perlakuan pre dan postes ada peningkatan pada hasil akhir yang dianalisis. Ditemukan adanya kemajuan yang signifikan diantaranta rata- rata skore 34 pada pre- tes dan skore post- test 73 . Metode Sustained Silent reading (SSR) pada mata kuliah Reading Comprehension adalah bisa diterapkan pada semester Dua jurusan bahasa Inggris di STKIP PGRI Bangkalan serta diharapkan pada mahasiswa memiliki kebiasaan membaca dengan baik dan dapat meningkatkan daya serap materi serta mampu menyelesaikan persoalan dengan mudah.

\section{Saran}

Berdasarkan hasil penelitian ini, peneliti mempunyai beberapa saran untuk meningkatkan memahami suatu teks dalam bahasa Inggris melalui metode Sustained Silent reading (SSR) adalah a) sebagai salah satu rujukan dalam pembelajaran mata kuliah Reading Comprehension b). Pengguna metode ini bisa mengontrol seluruh aktifitas yang telah direncanakan, c) memperbaiki apa yang menjadi kekurangan metode tersebut dalam meningkatkan aspek-aspek dalam pemahaman suatu teks.

\section{Ucapan Terima Kasih}

Ucapan terima kasih saya sampaikan kepada LPPM STKIP PGRI Bangkalan yang menyelenggarakan penelitian mandiri sehingga artikel ini terbit.

\section{Refference}

Gardiner , Steve.2005. Building student literacy through sustained silent reading. USA: ASCD

Gardiner, Steve. 2005. Building Student Literacy through Sustained Silent Reading. Heatherton, Vic: Hawker Brownlow Education.

Henry Guntur Tarigan. (2008). Membaca Sebagai Suatu Keterampilan Berbahasa. Bandung: AngkasaKrashen, Stephen. 2011. Free Voluntary Reading. Santa Barbara: Libraries Unlimited.

Redway, Kathryn. (1992). Membaca Cepat. Jakarta: Gramedia.

Satrijono, H. 2009. Keterampilan Bahasa Indonesia. Jember: Departemen Pendidikan Nasional Fakultas Keguruan Dan Ilmu Pendidikan Universitas Jember

Schleper, David R. 2002. ssr? dear? ussr? Or dirt?no matter what you call it, independent reading is for everyone. Dalam G41957 ODYSSEY FALL-02

Tampubolon. (1993). Mengembangkan Minat dan Kebiasaan Membaca Pada Anak. Bandung: Angkasa.

Tampubolon, DP. (1987). Kemampuan Membaca; Teknik Membaca Efektif dan Efisien. Bandung: Angkasa

https://www.gallaudet.edu/documents/clerc/ssr.pdf Siah, Poh- Chua; Kwok, War-Ling. (2010). The Value of Reading and the Effectiveness of Sustained Silent Reading. Journal of The Clearing House, 83 (5), 180-184. 